\title{
Environmental Law Enforcement as a Strategic Effort for Temple Sanctity Maintenance at Tourism Destination Area
}

\author{
N. L. M. Mahendrawati ${ }^{1}$ and I. B. Agustya Mahaputra ${ }^{2}$ \\ \{made.mahendrawati@gmail.com ${ }^{1}$ \} \\ Fakultas Hukum, Universitas Warmadewa, Denpasar, Bali - Indonesia
}

\begin{abstract}
Philosophically the sanctity of the temple is an entity that must be strictly guarded even though it has different aspects, namely the economic aspect as a support for tourism activities. This paper examines the essence of environmental law enforcement as a means that can be taken to maintain the sanctity of the temple. To achieve this objective, normative method was used with statutory, sociological, and philosophical approaches. The expected output from this study is the creation of constancy in the essence of the temples existence for local community (Balinese) so that the maintenance of temples goes hand in hand with the high rate of increase in tourism activities. Hence, the focus of the discussion is the aspect of environmental law and its enforcement as a form of usable strategic effort to maintain the temple sacredness in each tourism destination.
\end{abstract}

Keywords: Environmental law enforcement; sanctity of temple; tourism destination

\section{Introduction}

Temple is a place or area which in Hinduism is conceived as a place or "heaven" of the Holy [1]. Titib said that the temple or also referred to as heaven is a replica or imitation of the heaven/sthana of the Almighty God with His various manifestations in Loka Heaven [2]. A temple serves as a place of worship that is synonymous with trust in God in Hinduism [3][4]. Therefore, it is very natural if the temple is loaded with beautiful, fragrant, decent and magnificient things. By Titib, furthermore, it was stated that with the conception of a temple as a replica of a heaven in Hinduism, the temple must be holy and divine [2].

The terms "sacred" and "magnificient" are two meaningful words that are interrelated to each other in the context of temple as a place of worship for Hindus and so the concept is in line with the previous idea, that is, the sanctity and magnificience of the temple must be maintained and sustained[4, 5]. In line with developments in Indonesia, the pace of development is likened to a train that continues to run. Development in religious pluralism and belief in Indonesia certainly gives its own color in its actualization in society [6, 7]. "Temple" is located in the biological and social environment. In addition, in maintaining the sanctity of the temple, of course the realization of the harmony of values is absolutely necessary[8] [9]. The concept of sacred for Hindus is not necessarily seen as similar by that of other religious communities so that a solution that accommodates common interests applying between social classes or between religious communities needs to be sought. In this paper the solution in question is offered [9]. 
With regard to the object being investigated, the method used in this study is normative (doctrinal) method. This method is applied by making use of statutory, sociological, philosophical and juridical approaches to discover a model (strategy) in the form of ideas/thoughts for the maintenance of the sanctity of places of worship (temple), so that it can go hand in hand with the concept of environmental conservation in tourism areas. The legal material used as a guide for the review of this study is analyzed and presented qualitatively. This output is expected to provide a policy view that can accommodate the interests of all parties in the tourism area. Typically the concept of "magnificience" in the good quality of the environment associated with "sanctity" is offered as a policy strategy to accommodate the value of the "sanctity" that must be maintained in a temple and its surroundings.

This study applies normative study design. It deals with discussing the enforcement of legal aspects relating to environmental law and tourism, which in this case is of Bali, Indonesia. We also collected the related literature discussing the temple as a sacred place in Bali, which has become a huge attraction to both local and foreign tourists. We provide interpretation of the legal rules by narrating the story of temple as religious area for Hindus. We also collected studies on temple potential of being tourist attraction in other countries like those of India and some are from Korea and China.

\section{Discussion}

\subsection{Sustainable National Development with Environmental Insights}

National development is an effort carried out by all components of the nation in order to achieve the goal of statehood. The purpose of the state which is intended as the goal of the Indonesian state is outlined through the concept of 'the founding father' in the fourth paragraph of the opening of the 1945 Constitution of the Republic of Indonesia [10]. The purpose of a state is the orientation of the implementation of a country, which orientation cannot be separated from the nature of the existence of a country (especially in this context is the country of Indonesia). Philosophically-theoretically, it was found that the state emerged as a result of community agreements [11]. Adhering to the Pound's flow of thought "community agreement" is an agreement made by the community to hand over some of its rights to the authorities, which the authorities are given the right to regulate the common interests of the community so that the welfare of the community is realized [12]. Therefore, it can be said that all efforts carried out by all instruments of statehood are integrated, systematic and sustainable efforts in their aim to prosper the community as the purpose of a country. Additionally, Indonesia's national development is an absolute matter to be carried out in order to realize the goals of the country.

In order to actualize the national development, various policies of the authorities (in this case the government) are formed with an aim-oriented concept as described earlier. One of the manifestations of a structured national development effort is the establishment of a national development plan with a legal instrument in the form of Law Number 25 of 2004 concerning the National Development Planning System. Furthermore, national development plans are further divided into long-term development plan, medium-term development plan, and annual development plan. Reflecting the view of Pound in Atmadja's interpretation, it was found that law plays a central role in national development efforts [13]. A compelling legal characteristic is a pillar in engineering society in accordance with the established development 
plan. The flow of national development policies as stipulated in Law Number 25 of 2004 was later revealed in the form of systematic legal rules.

The term "systematic" in this context is aimed at harmonizing and synchronizing the rule of law in various fields regulated through legal instrument as a field that directly or indirectly supports the national development efforts. Therefore, any national development efforts are inseparable to legal policies regulating various aspects of public's interest in society. By means of Article 2 paragraph (1) of Law Number 25 of 2004, it is stipulated that "National development is carried out based on democracy with the principles of togetherness, justice, sustainability, environmental insight, and independence by maintaining the balance of national progress and unity". Grounded these underlying principles, the implementation of national development cannot be separated from various aspects, primarily the environment. It is that the environment is an important issue in the development given that human existence is always closely intertwined with its environment. In ecological view, humans in the physical environment surrounding always have an interdependent relationship, in the sense that in one view human activities always influence the condition of their physical environment. At the same time, the biophysical environment also influences the behavior of human. Building upon this concept, the basic assumption formulated is the environment is a disengageable entity to national development efforts.

Meanwhile, the provisions regarding the environment are regulated more specifically in Act No. 32 of 2009 concerning Environmental Protection and Management. In this act, it is explained that the living environment is a unity of space with all objects, power, circumstances, and living things, including humans and their behavior that affect the nature itself, the survival of life, and the welfare of humans and other living things (Article 1 number 1 Law No. 32 of 2009). The paradigm of thinking in this context is originated from the concept of "anthropocentric." Comparing Susilo's ideas about the philosophical view of Plato directs the way of thinking since it is stated that "plants are prepared for the benefit of animals and animals are provided for the benefit of humans". This proposition involves a deep understanding of the concept that regards humans as the center of life, in which everything in the world is always utilized to fulfill human's interests and their humanity interests are within the scope of "satisfaction". Satisfaction will excogitate happiness. The efforts of each individual or group of individuals to fulfill their interests continuously and without careful planning in order to obtain their personal happiness undoubtedly leads to the degradation of environmental quality which in turn threatens the existence of human beings themselves and other people in the world.

In relation to this phenomenon with development, the concept of sustainable development is regulated in Article 1 number 4 of Law No. 32 of 2009 as a conscious and planned effort that integrates environmental, social and economic aspects into a development strategy to ensure the integrity of the environment and the safety, ability, welfare and quality of life of present and future generations. In the conception of sustainable development (compare: sustainable national development), there is a change in the initial paradigm, where anthropocentric understanding is transformed by an ecological approach, as shown by the following figure, namely dialectic of antopocentric understanding in the context of the environment.
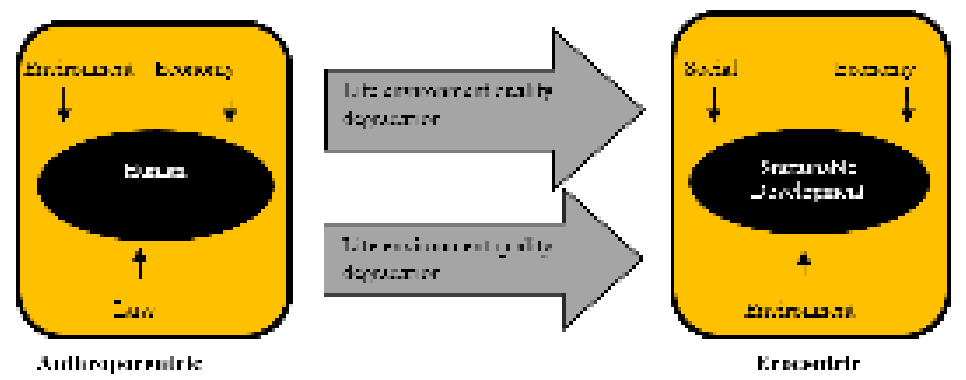
Fig. 1. Context of the environment.

Previous anthropocentric view, as shown by the figure, places humans as the center of life, where everything in the world is only used to fulfill human's interests. By means of ecological approach, the paradigm shifts to integrating all aspects. Humans are in a social realm that has the same position as the economy and the environment. Thus, human activities in social development must be integrated with economic development and sustainable environmental development.

\subsection{Temple as a Part of Human Socio-Religious Life (Hindus)}

Indonesia is a country formed with diversity, including religious diversity. Religion is understood as a doctrine/belief, the actualization of belief in God Almighty. Relying on the principle of diversity and human rights, Indonesian state guarantees the existence of each of its citizen (community) to embrace certain religion and practice their respective religions and beliefs. The rules regarding these guarantees are stipulated in the Indonesian written constitution (UUD NRI 1945) Article 29 paragraph (1) and (2). In this article, it is stated that everyone is guaranteed by the state to embrace religion and worship according to his/her religion and belief. It is clear that the diversity of religions and the beliefs of Indonesian citizens are recognized by the state through the First Precepts of Pancasila which reads "God Almighty". As is well known, Pancasila, the five principle of the republic of Indonesia, is the philosophical foundation and world view of life of Indonesia citizen. Through the sound of the First Precept of Pancasila, it can be stated that religion and belief that put trust in God Almighty and prossession of doctrines that are in line with the values of Pancasila are recognized and guaranteed by the state. One of the recognized religions in Indonesia is Hinduism, apart from Islam, Christianity, Catholicism, Buddhism and Confucianism. This is indicated by the inclusion of these religions in the profile of the Ministry of Religion of the Republic of Indonesia. In other words, the state directly participates in fostering and realizing the guarantee of religious embrace for every citizen and realizing the guarantee of harmony between adherents of different religions in Indonesia. Thus, government policies in the field of religion should be in line with government policies in other fields.

Hinduism is one of the religions in which the system believes that there is a sanctified place called Pura. The temple is believed to be the stana (place) of the gods as a manifestation of God Almighty (Ida Sang Hyang Widhi). Hence, there are rules that force every Hindu, that is, they must always maintain the sanctity of the temple. As is known, each religion has an institution as its adherent association to maintain its existence and protect its people in carrying out the realization of their religious beliefs and harmonizing the behavior of its adherents to the state life as a unity in the Law of Pancasila. The Hindu institutions in Indonesia are Parisadha Hindu Dharma Indonesia (PHDI). With regard to the existence of the Temple as a Hindu holy place whose preservation must be considered, PHDI issued instructions to its followers, namely instructions summarized in a decision or appeal. In connection with the sanctity of the temple, PHDI issued a decision on the Parisada Hindu Dharma Indonesia Pusat Number: 11/KEP/I/PHDIP/1994 concerning Bhisama Kesucian Pura. For a variety of holistic considerations, general provisions in the Bhisama are as follows:

1) Hinduism in its holy book, the Vedas, has described what is called the holy places and the Holy Area, Mount, Lake, Campuan (river mouth crossing), Coast, Sea and so on are believed to have purity values. Therefore, temples and holy places are generally established in that place because they are considered to be the place of saints 
2) These sanctuaries have become historic centres that gave birth to great and eternal works through the hands of saints and poets for the peace and prosperity of mankind. So, Sad Khayangan Temple, Dang Khayangan, Khayangan Tiga, and others were established. These sacred places have a chastity radius which is called an area of thickness with the size of Apeneleng Apenimpug, and Apenyengker. For Sad Khayangan Temple, the measure of Apeneleng Agung (minimum $5 \mathrm{Km}$ from Pura) is used, for Dang Khayangan, the measure of Apeneleng Alit (at least $2 \mathrm{kms}$ from Pura) is used, and for the Khayangan and others, the measure of Apenimpug or Apenyengker is used.

3) Given the increasingly rapid progress of development and Hindus who have socioreligious nature, in development activities the surrounding Hindus are included, namely from planning, implementing, to supervising, for the smooth development. Hinduism makes its people united with the environment; therefore, the concept of Tri Hita Karana must be applied as well. To maintain the balance between development and holy places, holy places (temples) need to be developed to maintain harmony with their environment.

4) With regard to the progress of increasingly rapid development, the development must be carried out in accordance with the established rules. In areas of the temple's chastity radius (small areas), only buildings related to Hindu religious life are allowed to be built, for example Dharmasala, Pasraman and others, in order to facilitate Hindus to perform their religious activities (eg Tirta Yatra, Dharma Wacana, Dharma Githa, Dharma Sedana and others).

"Apeneleng", "Apeneleng alat, "Apenimpug" or "Apenyengker" is the temple's sanctity radius. Of course the radius varies depending on the temple class concerned; each of them can enter Sad Kahyangan Temple, Dang Kahyangan Temple, or Kahyangan Tiga Temple and others. In line with the concept of "Tri Hita Karana" which is known in Hindus, a harmonious relationship is not only attempted to occur between humans and God (its creator) and between humans and other humans, but primarily is the creation of a harmonious relationship between human and their environment. The environment in question is an environment in which humans become part of the living and activities in it.

If it is associated with its practice in the field, the radius around the temple as stated in the PHDI decree has often experienced development by individuals, the private sector or the government. This physical development is realized in residential, tourism facilities or even industry. It is understood that socio-religious or cultural views differ from the views of national development in the physical field. However, it cannot be denied that the existence of religion, adherents of religion, and beliefs in these religions are also true (life) and continue to develop along with the civilization of society. Above all, to realize all designs, a systematic and sustainable policy including policies in the field of environment and religion that are able to run harmoniously is absolutely necessary. At least in realizing the development in question, the idea as a solution is needed as a basis for multisectoral insight including the environment and socio-religious (sanctity of the temple as a holy place of Hindus).

\subsection{Environmental Law Enforcement as an Instrument to Control Temples Sanctity in in Tourism Destination Areas}

Definition of law enforcement in the Black's Law Dictionary is: "1) the detection and punishment of violations of the law; 2) police officers and other member of the executive branch of goverment charged with carrying out and enforcing the criminal law" [14]. The essence of law enforcement according to Soekanto lies in harmonizing the relationship of 
values described in the principles that are solid and manifest and act as a series of final stages of value translation, to create, maintain and sustain the peace of life [15]. Furthermore, Rahmadi argued that environmental law enforcement is defined as the use or application of instruments and sanctions in the field of administrative law, criminal law and civil law, with the aim of imposing legal subjects who are the target to comply with environmental law and regulations [16]. Based on this concept, it can be conceived that before environmental law enforcement occurs, there is an environmental law that regulates what is permitted or prohibited under the threat of sanctions. Sanctions contained in the rules concerning environmental law aim to provide forced power so that everyone addressed in the regulation complies with legal provisions as contained in the legislation concerning the environment. Through Law No. 32 of 2009 Article 3, the purpose of environmental protection and management in Indonesia is regulated. It was stated explicitly that the scope of the objectives was concretized in its implementation in the form of planning, utilization, control, maintenance, supervision and law enforcement. Law enforcement is one of the instruments of environmental protection and management if there are legal subjects (individuals or corporations) who violate environmental aspects as determined in national development planning.

Law enforcement for violations of the provisions concerning the environment can be realized in the form of administration, civil or criminal. Law enforcement through administrative aspects is carried out thru administrative procedures as part of preventive efforts in protecting and managing the environment. What is meant here is the integration of administrative procedures in the form of licensing. For example, in the case of land use permits and building construction on a land that requires a series of permits issued by the regional government or provincial government. Presumably the administration aspect is integrated with the regional spatial plan as outlined in the regional regulations. Imposition of repressive administrative sanctions is carried out by the minister, governor, and regent/mayor to the person in charge of the business and/or activity if a violation of the environmental permit is found in the supervision. The administrative sanctions that can be imposed on legal subjects violating the provisions stipulated through the Act. 32 of 2009, among others, is a written warning, government coercion, suspension of environmental permits, and/or revocation of environmental permits.

Whenever pollution and environmental damage occur, there must be victims of them [17]. The victims can be people, individuals, communities or countries. Enforcement of environmental law through civil procedures is regulated in Chapter XIII Article 84 to Article 93. The civil aspects listed in these articles contain the resolution of environmental disputes that can be carried out through court (litigation) or non-court routes (non-litigation) based on the choice of parties who have voluntarily disputed. This provision is intended to protect the civil rights of the parties to the dispute. Settlement of off-court disputes can be done in a manner known as 'Alternative Dispute Resolution (ADR). The last legal instrument that can be used in enforcing environmental law is criminal law. Criminal sanctions can be imposed on any violator of the prohibition provisions contained in Law No. 32 of 2009. From the perspective of criminal law, there are several provisions which contain actions deemed as a criminal act (offense) in Law No. 32 of 2009. Environmental offenses regulated in several articles, including articles $41,42,43,44,45,46$, and article 47 . Some of the offenses referred to above are threatened with sanctions in the form of criminal sanctions. However, the use of criminal law instruments adheres to the principle of ultimum remidium, namely that criminal sanctions are used if other legal instruments (administrative and civil) are no longer applicable. 
Enforcement of environmental law (administrative, civil, or criminal) is expected to provide forced power to individuals or groups of individuals to behave or carry out all forms of activities with regard to environmental sustainability. Sustainability is intended to be sustainable across space and across generations. In the context of temple sanctity, environmental law enforcement can be described in a broader framework by referring to the term Steward as quoted by Susilo, namely that there is a dialectic or reciprocal relationship between culture and environment. In fact, Harris revealed that religion also has a reciprocal relationship with the environment [18]. The social structure of the tourism destination is certainly very heterogeneous considering that in the area of tourism there is cultural assimilation. In addition, it can also be understood that there are various tastes contained in subjective beliefs in each person. The possibility of differences in looking at something, especially the sanctity of a holy place (temples) has a large space to always occur. With regard to the sanctity of the temple, it can be concretely described that the sacred area that is trusted by Hindus is not necessarily a sacred area that is trusted by other religious communities around the temple [19]; especially if other people are intended to own land or a place of residence within the radius specified by PHDI as a sacred area of a temple.

This is considered very reasonable considering that religion is an actualization of a belief. Regarding the way to actualize these beliefs in the form of values or behavior is certainly different from each other in each religion. Trust is subjective because trust is rooted in the irrationalism of human thought. What is perceived appropriate in the behavior and values of the people of a particular religion (Hinduism) is not necessarily the same as what is felt by other religious communities. As a solution, a meeting point that is not rooted in taste, but rooted in ratios needs to be sought. What can be observed by the five senses of man is the root of human reasoning called ratio. To satisfy the values to each religious community including Hinduism (especially regarding the sanctity of the temple), a concrete thread that is capable of being judged equally by all religious people needs to be formed.

Put simply, what is implied through the concept of "holiness" contained in the Bhisama issued by PHDI is that there will be difficulties in the level of practice if it is only fixed on taste, because the sense of value is subjective for every religious person with one another. The concrete things that can be realized are cleanliness and environmental sustainability. The entity would be more concrete and could be positively captured by all religious people. To realize this, the concept of "holy" in Bhisama can be interpreted not only limited to the taste by Hindus but also on the view of cleanliness and environmental sustainability around the area where the temple is. This is because the provisions regarding cleanliness and environmental sustainability have been accommodated in the Law Law No. 32 of 2009 concerning Environmental Protection and Management. Hence, environmental law enforcement is one of the instruments in environmental conservation based on Law No. 32 of 2009 can be effectively applied to maintain the sanctity of temples.

What is felt sacred by Hindus, especially those related to the area of the temple, is not necessarily felt sacred by the people of other religions or beliefs. Notwithstanding, cleanliness and environmental sustainability are observations that can be felt as a common view by every religious community. Therefore, so that the value of purity felt by Hindus around the temple can be realized and supported by the entire community (not limited to people of other religions), environmental law enforcement efforts are needed. Through a clean and sustainable environment that is objective, a sense of holiness will be created for Hindus who are subjective. Therefore, presumably law enforcement against the environment is truly enforced through the National legal instrument (Law No. 32 of 2009) so that the value of sanctity as 
stated in the Bhisama PHDI concerning Purity of Temple can be realized through cleanliness and environmental sustainability.

\section{Conclusion}

Temple is a place that is believed by Hindus as a place of worship of God, where the temple is a reflection of heaven or sthana for God in all its manifestations. Based on these functions and values, the sanctity of the temple and its surroundings needs to be concerned and maintained. The value of purity that is rooted in the feelings of Hindus is not necessarily the same as the value of the sanctity rooted by other religious communities around the temple. So, a legal policy that applies nationally but still accommodates the interests of all religious people including Hinduism, especially related to the sanctity of the temple needs to be created. One of the policies in question is the policy of environmental law enforcement. With environmental law enforcement, every environment, including the surrounding environment, can be maintained, in terms of quality standard, regional spatial planning and sustainability. If this is able to be carried out consistently and continuously, the sanctity of the temple and the surrounding area can be realized.

Acknowledgments. The authors express the greatest gratitude to the organizing committee of the International Conference on Social Sciences (ICOSS) of Universitas Warmadewa for the great contribution that has been granted to the launching of this scientific script at EAI Publisher. Hopefully the ideas found in the paper can be additional to the theoretical and practical knowledge for many parties.

\section{References}

[1] Liang, M., Wang, $\mathrm{M}$ and $\mathrm{Xu}, \mathrm{S}$.: The Study of Temple Tourism Brand Marketing — Taking Guangxiao Temple as an Example. pp. 88-92 (2016)

[2] Titib, I, M.: Teologi dan Simbol-Simbol dalam Agama Hindu. Surabaya: Paramita (2001)

[3] In, T., Southern, T, H, E., Of, R and Ad, C.: the Holy Light : a Study of Natural Light in Hindu Century Ad To 17 the Holy Light : a Study of Natural Light in Hindu Temples in the Southern Region of Tamilnadu, India. no. August (2001)

[4] Singh, R, P, B.: Kardameshvara ( Kashi ) temple, a Religious Heritage from India : Sacred Landscape, Architectural Designs and Perspectives. (2018)

[5] Park, C, C.: Sacred Worlds: An Introduction to geography and religion. Vol. 16 (1997)

[6] Chin, W, L., Fraser, J, H and Hampton, M, P.: Destination competitiveness: evidence from Bali. Curr. Issues Tour.Vol. 20 (12). pp. 1265-1289 (2017)

[7] Ruastiti, N, M.: The Meaning of Baris Kraras Dance Performance at Mengwi, Badung, Bali in the Global Era. Vol. 8 (5). pp. 108-118 (2018)

[8] Griffin, K, A and Raj, R.: Editorial: The Importance of Religious Tourism and Pilgrimage: Reflecting on definitions, motives and data. Int. J. Relig. Tour. Pilgr. Vol. 5 (3) (2017)

[9] Cole, S and Browne, M.: Tourism and Water Inequity in Bali: A Social-Ecological Systems Analysis. Hum. Ecol. Vol. 43 (3). pp. 439-450 (2015)

[10] Nursamsi, D.: Kerangka Cita Hukum (Recht Idee) Bangsa Sebagai Dasar KewenanganMahkamah Konstitusi Menguji Peraturan Pemerintah Pengganti Undang- Undang (Perppu). J. Cita Huk. Vol. 134 (4). pp. 635-646 (2007)

[11] Mcmillan, D, W and Chavis, D. M.: Sense of Community-McMillan and Chavis. Vol. 14. pp. 
6-23 (1986)

[12] Dirdjosisworo, S.: Filsafat Hukum Dalam Konsepsi dan Analisa. Bandung: Alumni (1984)

[13] Atmadja, I, D, G.: Hukum Konstitusi Problematika Konstitusi Indonesia Sesudah Perubahan UUD 1945. Malang: Setara Press (2012)

[14] Bryan, G, A.: Black's Law Dictionary. Ninth. USA: West Publising (1999)

[15] Soekanto, S.: Faktor-Faktor Yang Mempengaruhi Penegakan Hukum. X. Jakarta: PT Raja Grafindo Persada (2011)

[16] Rahmadi, T.: Hukum Lingkungan Indonesia. Jakarta: Raja Grafindo Persada (2015)

[17] Azam, M., Alam, M. M and Hafeez, M. H.: Effect of tourism on environmental pollution: Further evidence from Malaysia, Singapore and Thailand. J. Clean. Prod. Vol. 190. pp. 330-338 (2018)

[18] Susilo, R, K, D.: Sosiologi Lingkungan. Jakarta: Rajawali Pers (2012)

[19] Excursions, F.: Favorite Excursions. Vol. 62 (10) (2018) 